Tampubolon, K. · F.N. Sihombing $\cdot$ Z. Purba $\cdot$ S.T.S. Samosir $\cdot$ S. Karim

\title{
Potensi metabolit sekunder gulma sebagai pestisida nabati di Indonesia
}

\section{Potency of secondary metabolite from weeds as natural pesticides in Indonesia}

Diterima : 28 Juli 2018/Disetujui : 10 Desember 2018 / Dipublikasikan : 31 Desember 2018

CDepartment of Crop Science, Padjadjaran University

\begin{abstract}
The purpose of review is to determine the benefits and mechanisms of secondary metabolites from weed, the advantages and disadvantages of natural pesticides from weed, identification of secondary metabolites from weed, procedures for making natural pesticides from weeds, and policy implications of natural pesticides from weed in controlling plant pests. The results of review showed that the potency of secondary metabolites from weeds can be multiple as natural pesticides. The advantages of natural pesticides from weeds included: (1) secondary metabolites from weeds that are organic and not toxic, (2) weeds are easily obtained from the field and do not require expensive costs, (3) several mechanisms of secondary metabolites from weed not found in the mechanism of synthetic pesticides, (4) weeds have more than one secondary metabolite of with multiple benefits in controlling pests, (5) does not cause toxication in crops, (6) can be combined with integrated pest control, (7) can be applied in an individual scale and farmer groups, and (8) do not cause pests, bacteria, nematodes, fungi, and other pests to become resistant. The weed phytochemical screening is needed to make precise pest controlling. Policies that carried out in the application of natural pesticides from weeds are: farmers are expected to extract and apply pesticides from weeds, and Ministry of Agriculture collaborates with

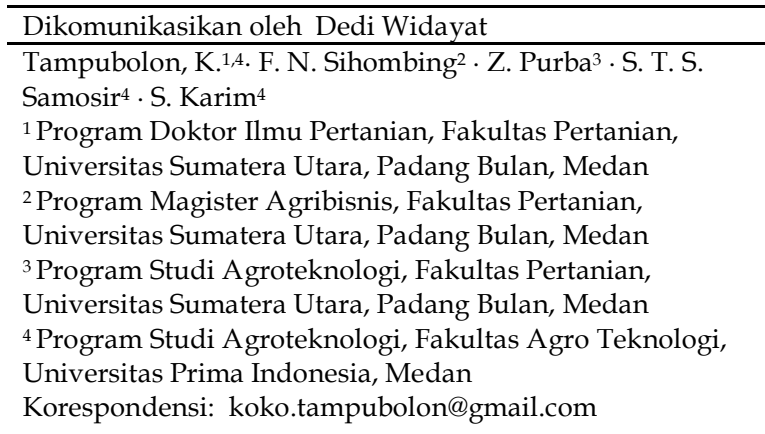

university or research institutions in secondary metabolites from weed testing, and forming farmer groups to producing and creating patent of natural pesticides from weeds.

Keywords: Natural pesticides $\cdot$ Secondary metabolite $\cdot$ Weed.

Sari. Tujuan kajian ilmiah ini adalah untuk mengetahui manfaat dan mekanisme metabolit sekunder gulma, kelebihan dan kekurangan pestisida nabati gulma, identifikasi metabolit sekunder gulma, prosedur pembuatan pestisida nabati dari gulma, dan implikasi kebijakan dari pestisida nabati gulma dalam mengendalikan organisme pengganggu tanaman. Hasil kajian menunjukkan potensi senyawa metabolit sekunder dari gulma dapat berfungsi ganda sebagai pestisida nabati. Kelebihan pestisida nabati dari gulma antara lain: (1) metabolit sekunder gulma bersifat organik dan tidak bersifat racun, (2) gulma yang digunakan mudah diperoleh dari lapangan dan tidak membutuhkan biaya yang mahal, (3) beberapa mekanisme metabolit sekunder gulma tidak ditemui dalam mekanisme kerja pestisida sintetis, (4) memiliki lebih dari satu metabolit sekunder setiap spesies gulma yang manfaatnya ganda dalam mengendalikan OPT, (5) tidak menimbulkan keracunan pada tanaman budidaya, (6) dapat dikombinasi dengan pengendalian hama terpadu, (7) dapat diterapkan dalam skala perorangan maupun kelompok tani, dan (8) tidak menyebabkan hama, bakteri, nematoda, jamur dan OPT lainnya menjadi resisten. Pengujian skrining fitokimia dari gulma diperlukan agar tepat sasaran dalam mengendalikan OPT. Kebijakan yang dilakukan dalam penerapan pestisida nabati dari gulma, antara lain: petani diharapkan dapat mengekstrak dan mengaplikasikan metabolit sekunder gulma, serta Kementerian 
Pertanian bekerja sama dengan lembaga penelitian atau universitas dalam pengujian metabolit sekunder gulma, dan membentuk kelompok tani dalam memproduksi serta menciptakan hak paten pestisida nabati dari gulma.

Kata kunci: Gulma - Metabolit sekunder . Pestisida nabati.

\section{Pendahuluan}

Keberadaan Organisme Pengganggu Tanaman (OPT) dalam aktivitas budidaya tanaman perlu dikendalikan secara berkelanjutan dengan tujuan dapat mengurangi dampak serangannya pada tingkat yang tidak merugikan secara ekonomi. Apabila OPT tidak dikendalikan maka dapat menyebabkan terjadinya penurunan kuantitas maupun kualitas hasil tanaman pertanian (Lumowa, 2011). Upaya pengendalian OPT membutuhkan biaya yang besar, seperti pembelian pestisida sintesis pada tanaman hortikultura dapat mencapai 30-40 \% dari total biaya produksi (Kardinan, 2010). Keberadaan pestisida sintesis di lahan pertanian dapat mengakibatkan efek samping yang serius seperti terjadinya pencemaran udara, tanah dan air, matinya organisme non sasaran (musuh alami), dan terjadinya resurjensi hama.

Petani di Indonesia sering kali menggunakan pestisida sintesis dengan dosis yang berlebihan. Penggunaan pestisida sintetis juga meninggalkan residu didalam tanah maupun tanaman serta dapat menyebabkan keracunan bagi petani dan konsumen. Kegiatan mengurangi biaya pengendalian OPT dan dampak negatif dari penggunaan pestisida sintetis, petani diharapkan mampu memproduksi sendiri formula pestisida nabati yang bahan aktifnya banyak tersedia dari lahan pertaniannya sendiri. Kurangnya informasi pengetahuan kepada petani di Indonesia mengenai manfaat metabolit sekunder dari gulma di lahan pertaniannya sehingga petani mengendalikan gulma tersebut dengan menggunakan herbisida maupun mekanis. Telah dilaporkan bahwa gulma memiliki senyawa penghambat (alelopati) yang dapat menjadi racun bagi hama, nematoda, rayap, bakteri, jamur dan gulma lainnya yang dapat merugikan petani.

Senyawa metabolit sekunder seperti fenolik, terpenoid, tanin, alkaloid, steroid, poliasetilena, dan minyak esensial pada gulma telah dilaporkan memiliki aktivitas alelopati (Junaedi et al., 2006). Senyawa fenolik dengan kelarutan dalam air tinggi dilaporkan memiliki aktivitas alelopati yang rendah. Sebaliknya senyawa fenolik dengan kelarutan dalam air rendah memiliki aktivitas alelopati yang tinggi (Rice, 1984; Seigler, 1996; Inderjit and Keating, 1999).

Menurut Wardhiany et al., (2014) menyatakan bahwa ekstrak gulma babadotan (Ageratum conyzoides) yang paling besar menekan populasi nematoda puru akar (Meloidogyne spp.) dalam $300 \mathrm{~g}$ tanah sebesar 97,4 $\%$. Lopez (2005) menyatakan senyawa tanin mampu melarutkan protein dalam kulit telur nematoda sehingga menyebabkan gagalnya pembentukan embrio, penetasan telur akibat rusaknya protein selubung telur terutama pada telur fase awal yang belum terbentuk larva nematoda. Vyvyan (2002) menyatakan bahwa mekanisme kerja senyawa alelopati antara lain berkaitan dengan sintesis asam amino (sintesis glutamina, aspartat aminotransferase), sintesis pigmen (sintesis asam livulenat (ALA)), fungsi plasma membran ( $\mathrm{H}^{+}$-ATPase, NADH oksidase), fotosintesis (CF1 ATPase), sintesis lipid (Asetil$\mathrm{CoA}$ transiklase, 3-oksoasil-ACP sintese, seramida sintase), dan sintesa asam nukleat (RNA polymerase, adenosilsuksinat sintase, AMP deaminase, isoleusil-t-RNA sintase).

Beberapa mekanisme tersebut tidak ditemui dalam mekanisme kerja pestisida sintetis, karena itu senyawa alelopati pada gulma sangat memiliki prospek untuk dimanfaatkan sebagai pestisida nabati. Alternatif penggunaan sumberdaya produksi yang ramah lingkungan perlu terus dikembangkan dan dioptimalkan pemanfaatannya. Untuk itu diperlukan pengkajian manfaat dan mekanisme metabolit sekunder gulma, kelebihan dan kekurangan pestisida nabati gulma, identifikasi metabolit sekunder gulma, prosedur pembuatan pestisida nabati dari gulma, dan implikasi kebijakan dari pestisida nabati gulma dalam mengendalikan organisme pengganggu tanaman.

\section{Manfaat dan Mekanisme Metabolit Sekunder Gulma}

Herbisida Nabati. Herbisida nabati merupakan herbisida berasal dari penggunaan beberapa organ tumbuhan. Kemampuan alelopati yang 
dihasilkan tanaman dalam mengendalikan pertumbuhan gulma dapat dimanfaatkan sebagai herbisida alami dalam sistem agrikultur yang kemampuannya sama dengan herbisida sintetik (El-Rokiek and Eid, 2009).

Beberapa penelitian penggunaan gulma sebagai herbisida nabati diketahui dapat menekan/mengendalikan pertumbuhan gulma lainnya. Menurut Isda et al., (2013) menyatakan bahwa ekstrak daun Ageratum conyzoides dapat menurunkan perkecambahan dan pertumbuhan serta meningkatkan persentase kerusakan pada anakan gulma Paspalum conjugatum. Konsentrasi ekstrak daun $20 \%$ merupakan konsentrasi optimum yang dapat menghambat perkecambahan, pertumbuhan dan meningkatkan persentase kerusakan anakan gulma Paspalum conjugatum berturut-turut sebesar 53,61 \%; 61,97 $\%$ dan $17,72 \%$.

Gejala kerusakan gulma, Paspalum conjugatum selain klorosis dan nekrosis yaitu terjadinya kelayuan pada gulma yang disebabkan karena adanya gangguan dalam berkas pengangkutan atau adanya kerusakan pada susunan akar yang menyebabkan penguapan dengan pengangkutan air tidak seimbang. Gejala kelayuan pada anakan gulma mulai terlihat pada konsentrasi $10 \%$ ekstrak (Isda et al., 2013).

Gulma Ageratum Conyzoides diketahui mengandung metabolit sekunder seperti flavonoid, alkaloid, terpena, kromen, kromon, benzofuran, kumarin, minyak atsiri, sterol dan tanin (Kamboj and Saluja, 2008). Senyawa fenol pada daun Ageratum conyzoides dapat menghambat pertumbuhan gulma. Menurut Wattimena (1987) gangguan mitosis oleh senyawa fenol disebabkan karena fenol merusak benangbenang spindel pada saat metafase. Hambatan pembelahan sel oleh senyawa alelokimia ekstrak daun Ageratum Conyzoides dapat pula melalui gangguan aktivitas hormon tumbuhan seperti sitokinin yang berperan dalam memacu pembelahan sel. Hambatan ini menyebabkan pembelahan sel pada bagian meristem pucuk terganggu sehingga menghambat pertumbuhan tinggi Paspalum conjugatum (Isda et al., 2013).

Perlakuan ekstrak daun Calopogonium mucunoides dapat menurunkan perkecambahan dan pertumbuhan, serta meningkatkan persentase kematian anakan gulma Asystasia gangetica. Penurunan pertumbuhan anakan gulma Asystasia gangetica dibanding kontrol mulai terjadi pada konsentrasi ekstrak $2 \%$ Calopo- gonium mucunoides, kecuali pada tinggi tanaman. Penurunan rerata tinggi anakan gulma dibandingkan kontrol mulai terjadi pada konsentrasi ekstrak $6 \%$. Penurunan pertumbuhan gulma semakin besar dengan meningkatnya konsentrasi ekstrak. Penghambatan perkecambahan dan pertumbuhan serta persentase kematian anakan gulma Asystasia gangetica yang tertinggi pada konsentrasi $54 \%$ ekstrak daun Calopogonium mucunoides (Sihombing et al., 2012).

Kandungan alelopati berupa senyawa fenol dalam ekstrak daun Calopogonium mucunoides dapat menghambat proses mitosis sel. Jika proses proliferasi sel terhambat, perbanyakan sel pada organ tumbuhan akan terhambat, sehingga pertumbuhan akan berjalan lambat bahkan terhenti. Menurut Einhellig (1995), senyawa fenol dan derivatnya seperti tanin dan flavonoid mempengaruhi beberapa proses penting seperti, penyerapan mineral, keseimbangan air, respirasi, fotosintesis, sintesis protein, klorofil dan fitohormon.

Menurut Sihombing et al., (2012) menyatakan bahwa konsentrasi ekstrak Calopogonium mucunoides yang tinggi akan mempengaruhi akar gulma dalam menyerap unsur hara. Kandungan flavonoid dan tanin dalam ekstrak Calopogonium mucunoides dapat merusak struk-tur membran sel sehingga permeabilitasnya akan menurun. Menurut Loveless (1991), gugus fenol sangat reaktif dengan protein untuk membentuk kompleks protein yang dapat menyebabkan kecenderungan penghambatan kerja enzim, yang merupakan salah satu proses metabolisme. Jika kerja enzim terganggu, maka proses penyerapan unsur hara dan air menjadi terhambat. Hal ini akan mengakibatkan terhambatnya proses fisiologi tumbuhan secara keseluruhan.

Hambatan perkecambahan karena senyawa-senyawa fenol yang terserap ke dalam biji menghambat metabolisme perombakan cadangan makanan. Perkecambahan dimulai setelah masuknya air yang akan menstimulasi aktivitas hormon dan enzim-enzim perkecambahan. Masuknya senyawa fenol seperti tanin akan berakibat merusak daya katalitik enzim perkecambahan terutama yang terkait dengan perombakan karbohidrat. Tanin dapat menghambat aktivitas enzim-enzim perkecambahan seperti selulase, poligalakturonase, proteinase, dehidrogenase dan dekarboksilase. Hambatan perkecambahan juga dapat disebabkan oleh gangguan senyawa fenol selama proses mitosis pada embrio (Einhellig, 1995). 
Menurut Pebriani et al., (2013) menyatakan bahwa pemberian ekstrak daun sembung rambat (Mikania micrantha) dengan konsentrasi ekstrak $15 \%$ mampu menghambat persentase perkecambahan, panjang kecambah dan tinggi tanaman Cleome rutidosperma. Konsentrasi 7,5 \% ekstrak daun sembung rambat mampu menghambat berat basah dan berat kering Cleome rutidosperma sedangkan konsentrasi 22,5 \% mampu menghambat persentase perkecambahan Paspalum notatum dan ekstrak konsentrasi $30 \%$ mampu menghambat berat basah dan berat kering Paspalum notatum.

Gulma sembung rambat (Mikania micrantha) memiliki senyawa alelokimia berupa fenol, flavonoid dan terpenoid yang dapat menghambat pertumbuhan tumbuhan lain (Perez et al., 2010). Menurut Kristanto (2006) senyawa alelokimia berupa fenol dan flavonoid lebih efektif menghambat aktivitas enzim selama proses perkecambahan. Kondisi ini menyebabkan proses perkecambahan menjadi terhambat, mengakibatkan menurunnya persentase perkecambahan. Fitter and Hay (1991) mengemukakan bahwa senyawa terpenoid, flavonoid dan fenol adalah alelokimia yang bersifat menghambat pembelahan sel.

Termitisida Nabati. Beberapa jenis rayap di Indonesia yang secara ekonomi sangat merugikan karena menjadi hama utama adalah tiga jenis rayap tanah/subteran (Coptotermes curvignathus, Macrotermes gilvus, serta Schedorhinotermes javanicus) dan satu jenis rayap kayu kering (Cryptotermes cynocephalus). Serangan rayap Coptotermes curvignathus pada tanaman di lapangan merupakan salah satu kendala utama yang perlu ditanggulangi. Hama ini dapat menimbulkan kerusakan fisik secara langsung pada tanaman dan menyebabkan terjadinya penurunan hasil, sehingga menimbulkan kerugian ekonomis yang cukup besar. Hal ini disebabkan rayap dapat menyerang akar dan batang tanaman sehingga translokasi air dan zat hara dari tanah terganggu dan akhirnya tanaman mati (Nandika et al., 2003).

Beberapa penelitian penggunaan metabolit sekunder dari gulma sebagai termitisida nabati dapat mengendalikan rayap. Menurut Salam et al., (2014) menyatakan bahwa perlakuan pemberian ekstrak Mikania micrantha dengan konsentrasi $6 \%$ dapat mengendalikan rayap (Coptotermes curvignathus) sebesar $100 \%$. Nilai $\mathrm{LC}_{50}$ diperoleh pada hari ke-9 dari 21 hari pengujian. Hal ini menunjukkan bahwa pada perlakuan konsentrasi $8.07 \%$ ekstrak Mikania micrantha dapat menyebabkan mortalitas rayap hingga $50 \%$. Penurunan persentase kehilangan berat kertas uji menunjukkan bahwa ekstrak Mikania micrantha mengurangi aktivitas makan rayap. Penurunan aktivitas makan rayap dapat disebabkan adanya kandungan terpenoid, saponin dan tanin dalam Mikania micrantha.

Barakat (2011) menyatakan bahwa senyawa a-pinene dapat menghambat enzim asetilkolinesterase, yang memecah asetilkolin (zat kimia penghantar rangsangan syaraf). Siramon et al., (2009) juga menyatakan bahwa terganggunya fungsi enzim asetilkolinesterase pada rayap menyebabkan asetilkolin terakumulasi sehingga terjadi inkoordinasi, paralisis dan kematian sel.

Insektisida Nabati. Insektisida nabati secara umum merupakan pestisida yang bahan aktifnya berasal dari bagian tumbuhan yang bersifat racun terhadap organisme pengganggu tanaman dan mempunyai metabolit sekunder yang mengandung berbagai senyawa bioaktif (Thamrin et al., 2013).

Beberapa penelitian penggunaan metabolit sekunder dari gulma sebagai insektisida nabati dapat mengendalikan hama pada tanaman budidaya. Menurut penelitian Thamrin et al., (2007) yang menyatakan bahwa ekstrak gulma kirinyu (Chromolaena odorata) mampu menyebabkan mortalitas ulat grayak (Spodoptera litura) hingga $100 \%$ pada 72 jam setelah aplikasi. Gejala keracunan terlihat setelah larva tersebut memakan daun sawi yang disemprot dengan insektisida nabati, gerakannya menjadi lambat dan aktivitas makannya berkurang, kemudian warnanya berubah menjadi kehitaman. Sampai hari ketiga sebagian besar larva mati. Hal ini mengindikasikan bahwa kandungan racun pada gulma Chromolaena odorata bersifat racun perut terhadap ulat grayak.

Gulma Chromolaena odorata juga dilaporkan memiliki senyawa Pyrrolizidine alkaloids (Thoden et al., 2007) yang merupakan senyawa sekunder yang diproduksi oleh tanaman dan berfungsi sebagai senyawa pertahanan tanaman terhadap herbivora (Rasmann and Agrawal, 2009). Pyrrolizidine alkaloids (PAs) dilaporkan dapat mengakibatkan mutagenesis pada serangga (Hartmann, 2004) seperti Drosophila melanogaster (Frei et al., 1992) dan juga telah dilaporkan bersifat toksik pada nematoda (Thoden et al., 2007) dan Philosamia ricini (Narberhaus et al., 2005).

Menurut Fitriana et al., (2012) menyatakan bahwa ekstrak gulma siam (Chromolaena odorata) dengan penambahan pengemulsi menghasilkan 
tingkat mortalitas imago Helopeltis spp. yang lebih tinggi dibandingkan dengan aplikasi ekstrak gulma siam tanpa penambahan pengemulsi. Tingkat mortalitas tertinggi dihasilkan pada ekstrak gulma siam pada tingkat konsentrasi $20 \%$ yaitu sebesar $46.67 \%$ (tanpa penambahan penemulsi) dan $71.67 \%$ (dengan penambahan pengemulsi). Penambahan pengemulsi ternyata dapat meningkatkan daya racun ekstrak gulma siam terhadap Helopeltis spp.

Penambahan deterjen sebagai pengemulsi akan dapat meningkatkan keterlarutan kandungan bahan aktif di dalam pestisida nabati sehingga akan dapat meningkatkan tingkat konsentrasi bahan aktif yang terkandung di suspensi ekstrak gulma Chromolaena odorata. Kemampuan ekstrak gulma Chromolaena odorata untuk menyebabkan kematian terhadap beberapa serangga diduga karena mengandung beberapa senyawa kimia yang bersifat toksik terhadap serangga. Owolabi $e t$ al., (2010) menyebutkan bahwa Chromolaena odorata mengandung beberapa senyawa kimia utama antara lain a-pinene $(42.2 \%)$, B-pinene (10.6\%), germacrene D $(9.7 \%)$, B-copaen-4a-ol $(9.4 \%),(E)$ caryophyllene $(5.4 \%)$, dan geijerene/ pregeijerene (7.5\%).

Menurut Kartika et al., (2016) yang menyatakan bahwa perlakuan konsentrasi ekstrak tepung daun babadotan $100 \mathrm{~g} / 1$ air merupakan konsentrasi yang lebih banyak dalam mematikan hama kepik hijau sebesar $72.50 \%$. Hal ini disebabkan semakin tinggi konsentrasi perlakuan ekstrak tepung daun babadotan maka kandungan bahan aktif senyawa precocene juga semakin tinggi, sehingga menyebabkan mortalitas total kepik hijau semakin besar. Senyawa aktif precocene masuk ke dalam tubuh kepik sebagai racun kontak melalui dinding tubuh kepik dan sebagai racun perut dengan masuk melalui alat mulut kepik.

Ekstrak tepung daun babadotan memiliki bahan aktif senyawa precocene dan masuk ke dalam tubuh kepik hijau selanjutnya bekerja sebagai racun saraf, yaitu dengan cara menghambat kerja enzim kholinesterase (Sembel, 2011). Enzim kholinesterase terhambat kerjanya karena senyawa precocene mengikat enzim kholinesterase yang berperan untuk menghidrolisis asetil kolin, sehingga asetil kolin tidak dapat melakukan fungsinya untuk menghantarkan rangsangan ke impuls saraf, sehingga mengakibatkan tergangunya aktifitas kepik. Terganggunya aktifitas kepik secara perlahan-lahan mengakibatkan kematian.
Fungisida Nabati. Fungisida nabati memiliki potensi menekan berbagai penyakit, termasuk antraknosa pada buah pisang, karena fungisida nabati mengandung bahan aktif yang bisa menghambat pertumbuhan patogen. Senyawa-senyawa aktif tersebut mampu menekan pertumbuhan patogen. Menurut Sekarsari (2013), minyak atsiri dapat berperan sebagai antibakteri dan antifungi.

Berdasarkan penelitian Arie et al., (2015) menunjukkan bahwa ekstrak teki, babadotan dan alang-alang dapat menekan pertumbuhan, sporulasi Colletotrichum musae secara in vitro dan keparahan penyakit antraknosa pada buah pisang secara in-vivo. Ekstrak teki dan babadotan lebih efektif dalam menekan pertumbuhan, sporulasi Colletotrichum musae dan keparahan penyakit antraknosa pada buah pisang. Ekstrak teki dan babadotan menunjukkan keefektifitasan yang sebanding dengan fungisida iprodion $50 \%$ dalam menekan keparahan penyakit antraknosa pada buah pisang.

Ekstrak teki, babadotan dan alang-alang berpengaruh dalam menekan pertumbuhan dan sporulasi Colletotrichum musae. Hal ini disebabkan karena ekstrak teki mengandung senyawa alkaloid, flavonoid, tanin, saponin, minyak atsiri, seskuiterpenoid (Fridiana, 2012). Ekstrak babadotan dapat berfungsi sebagai fungisida nabati karena mengandung senyawa minyak atsiri, saponin, flovanoid, polifenol, HCN, alkaloid,dan kumarin (Setiawati et al., 2008). Ekstrak alang-alang juga dapat menekan pertumbuhan Colletotrichum musae, karena alang-alang mengandung alkaloid, flavonoid, mannitol, asam malat, asam sitrat, coixol, arundoin, silindrin, fernerol, simiarenol, anemonin, esin, alkali, saponin, taninin, dan polifenol (Gusmarini, 2013).

Nematisida Nabati. Nematoda Meloidogyne spp. adalah salah satu OPT penting dunia yang cukup sulit dikendalikan karena kisaran inang yang luas dan perkembangannya yang cepat. Serangan nematoda Meloidogyne spp. Menyebabkan kerugian produksi tanaman mencapai 17-40 \% (Dropkin, 1996).

Beberapa penelitian penggunaan metabolit sekunder dari gulma sebagai nematisida nabati dapat mengendalikan nematoda. Menurut Wardhiany et al., (2014) menyatakan bahwa ekstrak tanaman yang paling besar menekan populasi nematoda puru akar (Meloidogyne spp.) dalam $300 \mathrm{~g}$ tanah adalah ekstrak gulma Ageratum 
conyzoides (babadotan) yaitu sebesar $97.4 \%$. Ekstrak tanaman yang paling besar menekan populasi nematoda dalam $1 \mathrm{~g}$ akar adalah ekstrak gulma Lantana camara (kerasi) yaitu sebesar 92.6 \%. Ekstrak gulma Chromolaena odorata, Ageratum conyzoides, Lantana camara, Imperata cylindrica, dan Marsilea crenata mampu menekan populasi nematoda adalah karena adanya kandungan senyawa tanin dalam masing-masing ekstrak tersebut. Lopez (2005) yang menyatakan senyawa tanin mampu melarutkan protein dalam kulit telur nematoda sehingga menyebabkan gagalnya pembentukan embrio, penetasan telur akibat rusaknya protein selubung telur terutama pada telur fase awal yang belum terbentuk larva nematoda. Senyawa tanin juga mampu mengendapkan protein. Efek tanin terhadap dinding sel kulit larva adalah dapat memblokade respon otot nematoda terhadap asetil kolin sehingga nematoda menjadi lumpuh dan mati. Lopez (2005) juga mengatakan bahwa tanin dapat menghambat sistem enzimatik nematoda dan bereaksi dengan protein penyusun sel-sel sehingga dapat mengurangi kemampuan nematoda dalam menginfeksi akar.

Menurut Huzni et al., (2015) menyatakan bahwa aplikasi ekstrak Chromolaena odorata pada 4 level konsentrasi dalam 3 tingkat waktu tertentu mampu menyebabkan kematian terhadap juvenil II dan mengurangi daya tetas telur Meloidogyne spp. Tingkat pengaruh yang paling tinggi terdapat pada konsentrasi $20 \%$ ekstrak $C$. odorata dengan tingkat daya hambat tetas telur dan mortalitas juvenil II Meloidogyne spp. hingga $100 \%$.

Kematian juvenil II Meloidogyne spp. disebabkan oleh senyawa aktif dari ekstrak gulma Chromolaena odorata memiliki senyawa alkaloid, flavonoid, tanin dan saponin. Senyawa flavonoid mempunyai sifat lipophilic yang dapat meleburkan membran sitoplasmik sel nematoda dan mengganggu fungsional struktur enzim protein dari nematoda (Ojo and Umar, 2013).

\section{Kelebihan dan Kelemahan Pestisida Nabati dari Gulma}

Kelebihan-kelebihan pestisida nabati dari gulma dibandingkan dengan pestisida sintesis (kimiawi), antara lain:

1. Berkontribusi dalam menjaga kesehatan lingkungan (udara, air, dan tanah) dikarenakan metabolit sekunder gulma bersifat organik dan tidak bersifat racun bagi biota tanah dan air, serta tidak mencemari udara.

2. Bahan (gulma) yang digunakan mudah diperoleh dari lapangan dan tidak membutuhkan biaya yang mahal.

3. Beberapa mekanisme metabolit sekunder gulma tersebut tidak ditemui dalam mekanisme kerja pestisida sintetis.

4. Memiliki lebih dari satu metabolit sekunder setiap spesies gulma yang manfaatnya ganda dalam mengendalikan OPT, contohnya gulma sembung rambat (Mikania micrantha) dapat dijadikan sebagai insektisida, herbisida, dan atau fungisida nabati.

5. Tidak menimbulkan keracunan pada tanaman budidaya.

6. Dapat dikombinasi dengan pengendalian hama terpadu (PHT).

7. Dapat diterapkan dalam skala perorangan maupun kelompok tani.

8. Tidak menyebabkan hama, bakteri, nematoda, jamur dan OPT lainnya menjadi resisten terhadap pestisida.

Beberapa kekurangan pestisida nabati dari gulma, antara lain:

1. Mekanismenya dalam mengendalikan OPT tergolong lambat dikarenakan bersifat racun saraf dan lambung, sehingga mengganggu koordinasi saraf dan pencernaan hama.

2. Cepat mengalami oksidasi sehingga tidak dapat disimpan lama, maka diperlukan penambahan adjuvant dalam menjaga kualitas pestisida nabati dari gulma. Menurut Dadang dan Prijono, (2011) menyatakan bahwa penambahan adjuvant Agristik dalam menjaga kestabilan formulasi insektisida nabati dalam mengendalikan Crocidolomia pavonana pada tanaman sayuran.

3. Efek metabolit sekunder gulma ini tidak bersifat langsung dalam mematikan OPT.

4. Pengaplikasian pestisida nabati dari gulma harus dilakukan berulang-ulang, hal ini disebabkan senyawa dalam ekstrak gulma ini cepat terurai dilapangan.

5. Tidak dapat diproduksi dalam skala besar sehingga diperlukan pembuatan pestisida nabati gulma secara intens.

\section{Identifikasi Metabolit Sekunder Gulma Sebagai Pestisida Nabati}

Sebelum melakukan pembuatan pestisida nabati, maka diperlukan pengujian atau 
identifikasi metabolit sekunder yang terdapat pada ekstrak daun maupun batang gulma yang akan digunakan. Pengujian ini dilakukan dengan mengambil sampel gulma yang berada di lahan petani sendiri. Setelah diperoleh kandungan dan komposisi metabolit sekunder yang terbaik berdasarkan sasarannya OPT dari beberapa gulma maka dilakukan pemilihan gulma yang menjadi bahan baku utama dalam memperbanyak pestisida nabati. Pengujian ini dapat dilakukan dengan kerjasama antara petani/kelompok tani dengan lembaga penelitian pemerintah daerah, pusat maupun universitas.

Prosedur pengujian metabolit sekunder ini antara lain :

a. Batang dan daun gulma yang segar dicampur dan dihomogenkan dengan blender pada suhu kamar.

b. Diambil $5 \mathrm{~g}$ setiap gulma yang homogen ditambahkan dengan $10 \mathrm{~mL} 70 \%$ (v/v) etanol dan dicampur dengan mixer vortex selama 5 menit. Ekstrak disentrifuse pada $2000 \mathrm{r} /$ menit selama 10 menit pada suhu kamar. Supernatan disesuaikan dengan volume akhir untuk $10 \mathrm{~mL}$.

c. Pengujian metabolit Alkaloid, dengan mengambil $1 \mathrm{ml}$ ekstrak gulma dicampur dengan $1 \%$ asam klorida dan direbus pada $95^{\circ} \mathrm{C}$ selama 10 menit. Kemudian ditambahkan dengan dua tetes Wagner's reagen (1.27 g yodium dan $2.0 \mathrm{~g}$ ion kalium di $100 \mathrm{~mL}$ air aquades). Endapan coklat kemerahan menunjukkan hasil positif.

d. Pengujian metabolit Saponin, dengan cara merebus $1 \mathrm{~mL}$ ekstrak gulma untuk 10 menit dan kemudian dicampur dengan $5 \%$ larutan natrium karbonat. Kemudian campuran diguncang. Pembentukan busa menunjukkan kandungan saponin.

e. Pengujian metabolit Tanin, dengan mencampur $0.5 \mathrm{~mL}$ dari ekstrak gulma dengan $0.1 \mathrm{~mL}$ dari $1 \%$ larutan besi klorida, dan endapan kuning menunjukkan kandungan tanin.

f. Pengukuran metabolit Fenolik, dengan metode spektrometri (Sherikar and Mehta, 2012). Diencerkan $200 \mu \mathrm{L}$ dari ekstrak gulma kemudian dicampur dengan $1 \mathrm{~mL}$ dari 0.1 $\mathrm{mol} / \mathrm{L}$ Folin-Ciocalteu reagen. Setelah itu dibiarkan pada kondisi gelap dengan suhu kamar selama 30 menit, $800 \mu \mathrm{L}$ dari $7 \%$ natrium karbonat ditambahkan ke dalam larutan. Absorban warna biru yang dihasilkan diukur pada $750 \quad \mathrm{~nm}$ menggunakan asam galat (larutan standar).

g. Pengukuran metabolit Flavonoid, menggunakan aluminium klorida dengan metode kolorimetri (Kiranmai, et al., 2011). Dicampurkan methanol (1.5 mL), $0.1 \mathrm{~mL}$ dari $10 \%$ aluminium klorida, $0.1 \mathrm{~mL}$ dari 1 mol/L kalium asetat dan $2.8 \mathrm{~mL}$ air aquades dengan $0.5 \mathrm{~mL}$ dari larutan ekstrak gulma dan kemudian diinkubasi pada suhu kamar selama 30 menit. Absorban diukur pada 415 $\mathrm{nm}$ menggunakan quercetin sebagai standar.

\section{Prosedur Pembuatan Pestisida Nabati dari Gulma}

Setelah melalui pengujian potensi metabolit pada gulma, maka langkah selanjutnya dengan membuat pestisida nabati dengan formulasi yang tepat, sesuai dengan sasaran OPT di lahan petani.

Prosedur pembuatan pestisida nabati dari gulma ini yang dapat diterapkan oleh petani (Gambar 1) sebagai berikut:

a. Mengumpulkan gulma-gulma berpotensi dari areal tanaman petani sendiri seperti Ageratum conyzoides, Euphorbia hirta, Imperata cylindrica, Cyperus rotundus, Mikania micrantha, Calopogonium mucunoides, Chromolaena odorata, Marsilea crenata, dan gulma lainnya.

b. Daun dan batang gulma ditimbang sebanyak $25 \mathrm{~g}$ berat segar (contohnya konsentrasi ekstrak $5 \%$ ) dicampur dengan aquades $500 \mathrm{~mL}$ kemudian diblender hingga halus. Cara yang sama juga dilakukan untuk konsentrasi ekstrak $10 \%$ dari $100 \mathrm{~g}$ berat segar, $15 \%$ dari $150 \mathrm{~g}$ berat segar, $20 \%$ dari $200 \mathrm{~g}$ berat segar, $25 \%$ dari $250 \mathrm{~g}$ berat segar.

c. Ekstrak tersebut kemudian disaring dan didiamkan selama 24 jam dalam suhu ruang, serta esktrak tersebut jangan sampai teroksidasi.

d. Untuk menentukan formulasi yang tepat pada sasaran OPT, maka dilakukan pengujian sederhana terlebih dahulu dengan membuat plot percobaan di lahan kelompok tani.

e. Pemberian ekstrak gulma terhadap hama, rayap, nematoda maupun OPT lainnya dilakukan dengan cara penyemprotan sebelum jam 10 pagi. Pemberian ekstrak dilakukan setiap 3 hari sekali selama 4 minggu waktu pengamatan. 


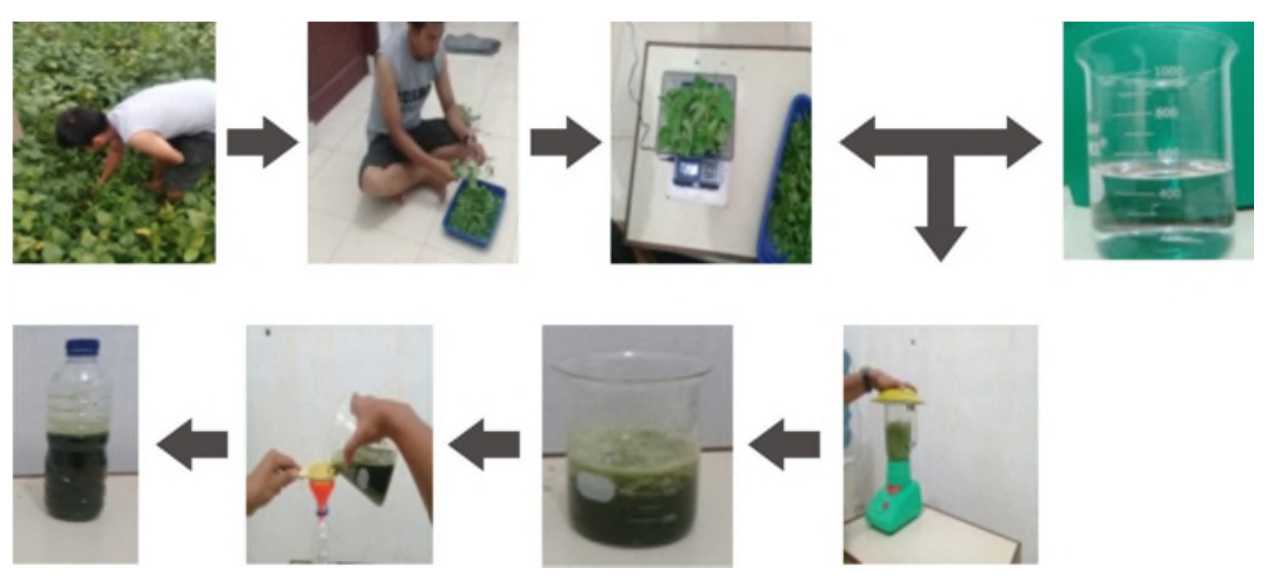

Gambar 1. Prosedur pembuatan pestisida nabati dari gulma Ageratum conyzoides dengan ekstrak
aquades secara sederhana yang dapat diterapkan petani.

f. Setelah itu kelompok tani dan pemerintah daerah mendaftarkan produk pestisida nabati untuk membuat hak paten. Salah satu kelemahan pestisida nabati selama ini adalah nilai jual yang rendah. Hal ini disebabkan tidak adanya lembaga penelitian yang mematenkan produk ini. Apabila sudah dipatenkan nilai jual akan menjadi tinggi.

\section{Implikasi Kebijakan Pestisida Nabati Gulma}

Program penerapan pestisida nabati dari gulma diharapkan dapat menekan penggunaan pestisida kimiawi sehingga dapat menjaga keseimbangan ekosistem dan menjaga kesehatan lingkungan.

Beberapa implikasi kebijakan yang dapat diterapkan dalam mendukung pestisida nabati dari spesies gulma, antara lain:

1. Kepada petani diharapkan dapat membuat pestisida nabati dengan mengambil gulma dilahannya sendiri kemudian mengesktrak dan mengaplikasikan langsung ke tanaman yang terserang OPT.

2. Kementerian Pertanian bekerja sama dengan lembaga penelitian universitas disetiap provinsi untuk melakukan penelitian mengenai keragaman dan kualitas metabolit sekunder dari gulma lainnya beserta peranannya dalam mengendalikan OPT.

3. Kementerian Pertanian melalui Dinas Pertanian setiap kabupaten dapat membentuk kelompok tani dalam memproduksi pestisida nabati dari gulma.
4. Kementerian Pertanian melalui kelompok tani bekerja sama dengan kelembagaan/ instansi pemasaran produk pertanian dalam menciptakan hak paten dan memasarkan pestisida nabati dari gulma.

\section{Kesimpulan}

1. Potensi senyawa metabolit sekunder dari beberapa gulma dapat berfungsi ganda sebagai herbisida, termisida, fungisida, insektisida, dan nematisida nabati.

2. Kelebihan pestisida nabati dari gulma antara lain: (a) metabolit sekunder gulma bersifat organik dan tidak bersifat racun, (b) gulma yang digunakan mudah diperoleh dari lapangan dan tidak membutuhkan biaya yang mahal, (c) beberapa mekanisme metabolit sekunder gulma tidak ditemui dalam mekanisme kerja pestisida sintetis, (d) memiliki lebih dari satu metabolit sekunder setiap spesies gulma yang manfaatnya ganda dalam mengendalikan OPT, (e) tidak menimbulkan keracunan pada tanaman budidaya, (f) dapat dikombinasi dengan pengendalian hama terpadu, (g) dapat diterapkan dalam skala perorangan maupun kelompok tani, dan (h) tidak menyebabkan hama, bakteri, nematoda, jamur dan OPT lainnya menjadi resisten terhadap pestisida.

3. Pengujian skrining fitokimia dari gulma diperlukan agar tepat sasaran dalam mengendalikan OPT.

4. Pembuatan pestisida nabati dari gulma yang mudah diterapkan oleh petani dapat menggunakan ekstrak aquades. 
5. Beberapa kebijakan yang dilakukan dalam penerapan pestisida nabati dari gulma, antara lain: (a) petani diharapkan dapat mengambil, mengekstrak, dan mengaplikasikan metabolit sekunder gulma, (b) Kementerian Pertanian bekerja sama dengan lembaga penelitian universitas dalam pengujian metabolit sekunder gulma, (c) Kementerian Pertanian melalui Dinas Pertanian setiap kabupaten dapat membentuk kelompok tani dalam memproduksi pestisida nabati dari gulma dan memasarkan, serta menciptakan hak paten pestisida nabati dari gulma.

\section{Daftar Pustaka}

Arie, I. Z., J. Prasetyo, dan Efri. 2015. Pengaruh Ekstrak Alang-Alang, Babadotan dan Teki Terhadap Penyakit Antraknosa pada Buah Pisang Kultivar Cavendish. J. Agrotek Tropika, 3 (2): 251-256.

Barakat, D. A. 2011. Insecticidal and Antifeedant Activities and Chemical Composition of Casimiroa Edulis La Llave \& Lex (Rutaceae) Leaf Extract and its Fractions Against Spodoptera littoralis Larvae. Aust J Basic Appl Sci, 5 (9): 693-703.

Dadang, dan D. Prijono. 2011. Pengembangan Teknologi Formulasi Insektisida Nabati untuk Pengendalian Hama Sayuran dalam Upaya Menghasilkan Produk Sayuran Sehat. J. Ilmu Pertan. Indones, 16 (2): $100-111$

Dropkin, V. H. 1996. Pengantar Nematologi Tumbuhan Edisi Kedua. (Terjemahan). Gadjah Mada University Press. Yogyakarta.

Einhellig FA. 1995. Interactions Involving Allelopathy in Cropping Systems. Agron. J, 88 (6): 886-893.

El-Rokiek, K. G. and R. A. Eid. 2009. Allelopathic Effects of Eucalyptus citriodora on Amaryllis and Associated Grassy Weed. Planta Daninha, 27 : 887-899.

Fitriana, Y., Purnomo dan A. M. Hariri. 2012. Uji Efikasi Ekstrak Gulma Siam Terhadap Mortalitas Hama Pencucuk Buah Kakao (Helopeltis SPP.) di Laboratorium. J. HPT. Tropika, 12 (1): 85-91.

Fitter, A. H and R. K. M. Hay. 1991. Fisiologi Lingkungan Tanaman. Yogyakarta: Gadjah Mada Press.
Frei, H., J. Luthy., J. Brauchli., U. Zweifel., F. E. Wurgler, and C. Schlatter. 1992. Structure/Activity Relationships of the Genotoxic Potencies of Sixteen Pyrrolizidine Alkaloids Assayed for the Induction of Somatic Mutation and Recombination in Wing Cells of Drosophila melanogaster. Chem. Biol. Interact, 83 (1): 1-22.

Fridiana, D. 2012. Uji Antiinflamasi Ekstrak Umbi Rumput Teki (Cyperus rotundus L.) pada Kaki Tikus Wistar Jantan yang Diinduksi Karagen. Skripsi Universitas Jember.

Gusmarini, M. 2013. Pengaruh Beberapa Jenis Ekstrak Tumbuhan terhadap Penyakit Antraknosa pada Tanaman Cabai Besar di Lapangan. Skripsi Universitas Lampung.

Hartmann T. 2004. Plant-Derived Secondary Metabolites as Defensive Chemicals in Herbivorous Insects: a Case Study in Chemical Ecology. Planta, 219 (1): 1- 4.

Huzni, M., B. T. Rahardjo., dan Hagustarno. 2015. Uji Laboratorium Ekstrak Kirinyuh (Chromolaena odorata King \& Robinson) Sebagai Nematisida Nabati Terhadap Meloidogyne spp. J. HPT, 3 (1): 93-101

Inderjit, Keating KI. 1999. Allelopathy: principles, procedures, processes, and promises for biological control. Di dalam: Sparks DL (ed). Adv Agron Vol 67. San Diego: Acad Press. pp 141-231.

Isda, M. N., S. Fatonah dan R. Fitri. 2013. Potensi Ekstrak Daun Gulma Babadotan (Ageratum conyzoides L.) Terhadap Perkecambahan dan Pertumbuhan Paspalum conjugatum Berg. J. Biol, 6 (2): 120-125.

Junaedi, A., M. A. Chozin, and K. H. Kim. 2006. Ulasan Perkembangan Terkini Kajian Alelopati. HAYATI J. Biosci, 13 (2): 79-84

Kamboj, A. and Saluja. 2008. Ageratum conyzoides L.: A Review on its Phytochemical and Pharmacological Profile. Int. J. Green Pharm, 59-68.

Kardinan, A. 2010. Prospek dan Kendala dalam Pengembangan dan Penerapan Penggunaan Biopestisida di Indonesia. hlm. 1-13. Pros. Sem. Nas. VI Perhimpunan Entomologi Indonesia. Bogor, 24 Juni 2010

Kartika, N. I., D. Salbiah dan A. Sutikno. 2016. Uji Beberapa Konsentrasi Ekstrak Tepung Daun Babadotan (Ageratum conyzoides L.) dalam Mengendalikan Kepik Hijau 
(Nezara viridula L.) pada Kacang Panjang (Vigna sinensis L.). JOM. Faperta, 3 (1): 1-11

Kiranmai, M., M. Kumar, and I. Mohammed. 2011. Comparison of Total Flavanoid Content of Azadirachta indica Root Bark Extracts Prepared by Different Methods of Extraction. Res. J. Pharm. Biol. Chem. Sci, 2 (3): 254-261.

Kristanto, B.A. 2006. Perubahan Karakter Tanaman Jagung (Zea mays L.) Akibat Alelopati dan Persaingan Teki (Cyperus rotundus L.). J. Indon. Trop. Anim. Agric, 31 (3): 189-194.

Lopez. 2005. In Vitro Effect of Condosed Tannins from Tropical Fodder Crops Againts Eggs and Larvae of the Nematode Haemunchus contortus. J.Food Agric. Environ. 3(2):191-194.

Loveless, A. R. 1991. Prinsip-Prinsip Biologi Tumbuhan untuk Daerah Tropik. Jilid 1. Jakarta : PT.Gramedia Pustaka.

Lumowa, S. V. V. 2011. Efektivitas Ekstrak Babadotan (Ageratum conyzoides L.) Terhadap Tingkat Kematian Larva Spodoptera litura F. Eugenia, 17 (3): 186-191.

Nandika, D., Y. Rismayandi, dan F. Diba. 2003. Rayap, Biologi dan Pengendalian. Muhammadiyah Univ. Press, Surakarta

Narberhaus, I., V. Zintgraf, and S. Dobler. 2005. Pyrrolizidine Alkaloids on Three Trophic Levels Evidence for Toxic and Deterrent Effects on Phytophages and Predators. Chemoecology, 15 (2): 121-125.

Ojo, G. T and I. Umar. 2013. Evaluation of Some Botanicals on Root - Knot Nematode (Meloidogynejavanica) in Tomato (Lycopersiconesculentum, Mill) in Yola Adamawa State, Nigeria. Biol. Forum, 5 (2): 31-36

Owolabi, M. S., A. Ogundajo., K. O. Yusuf., L. Lajide., H. E. Villanueva., J. A. Tuten and W. N. Setzer. 2010. Chemical Composition and Bioactivity of the Essential Oil of Chromolaena odorata from Nigeria. Rec. Nat. Prod. 4 (1): 72-78.

Pebriani., R. Linda., dan Mukarlina. 2013. Potensi Ekstrak Daun Sembung Rambat (Mikania micrantha H.B.K) Sebagai Bioherbisida terhadap Gulma Maman Ungu (Cleome rutidosperma D.C) dan Rumput Bahia (Paspalum notatum Flugge). Jurnal Protobiont, 2 (2): 32-38.

Perez, A. M. C., V. M. Ocotero., R. I. Balcazari, dan F. G. Jimenez. 2010. Phytochemical and Pharmological Studies on Mikania micrantha H.B.K. Int. J. Exp. Bot, 78 : 77-80.
Rasmann, S and A. A. Agrawal. 2009. Plant Defense Against Herbivory: Progress in Identifying Synergism, Redundancy, and Antagonism Between Resistance Traits. Curr. Opin. Plant Biol, 12 (4): 473-478.

Rice, E. L. 1984. Allelopathy. Edisi kedua. Orlando: Acad Press.

Salam, D. M., Mukarlina., dan F. Diba. 2014. Pengendalian Rayap Tanah Coptotermes curvignathus Holmgren Menggunakan Ekstrak Daun Gulma Sembung Rambat (Mikania micrantha Kunth). Protobiont, 3 (2): 87-92.

Seigler, D. S. 1996. Chemistry and Mechanisms of Allelopathic Interactions. Agron. J, 88 (6): 876-885.

Sekarsari, A. R. 2013. Pengaruh Beberapa Fungisida Nabati Terhadap Keterjadian Penyakit Bulai pada Jagung Manis (Zea mays saccharata). J. Agrotek Tropika, 1 (1): 98-101.

Sembel, D. 2011. Dasar-Dasar Perlindungan Tanaman. Penerbit Andi. Bandung.

Setiawati, S., R. Murtiningsih., N. Gunaeni, dan T. Rubiati. 2008. Tumbuhan Bahan Pestisida Nabati dan Cara Pembuatannya untuk Pengendalian Organisme Penggangu Tumbuhan (OPT). Prima Tani Balitsa. pp. 16-17.

Sherikar, O. D., and P. J. Mehta. 2012. Development and Validation of RPHPLC, UV-Spectrometric and Spectrophotometric Method for Estimation of Tapentadol Hydrochloride in Bulk and in Laboratory Sample of Tablet Dosage Form. J. Chem. Pharm. Res, 4 (9): 4134-4140.

Sihombing. A., S. Fatonah, dan F. Silviana. 2012. Pengaruh Alelopati Calopogonium mисиnoides Desv. terhadap Perkecambahan dan Pertumbuhan Anakan Gulma Asystasia gangetica (L.) T. Anderson. Biospecies, 5 (2): 5-11.

Siramon, P., Y. Ohtani, and H. Ichiura. 2009. Biological Performance of Eucalyptus camaldulensis Leaf Oils From Thailand Against The Subterranean Termite Coptotermes formosanus Shiraki. J. Wood Sci, 55 (1): 41-46.

Sitepu, D., A Kardinan, dan A. Asman. 1999. Hasil Penelitian, dan Peluang Penggunaan Pestisida Nabati. Pengembangan Teknologi Tanaman Rempah dan Obat, 9 (2): 25-33. 
Thamrin, M., S. Asikin., dan M. Willis. 2013. Tumbuhan Kirinyu Chromolaena odorata (L) (Asteraceae: Asterales) Sebagai Insektisida Nabati untuk Mengendalikan Ulat Grayak Spodoptera litura. J. Penelitian dan Pengembangan Pertanian, 32 (3): 112-121

Thamrin, M., S. Asikin., Mukhlis, dan A. Budiman. 2007. Potensi Ekstrak Flora Lahan Rawa Sebagai Pestisida Nabati. Balai penelitian Pertanian Lahan Rawa, 35-54.

Thoden, T. C., M. Bppre, and J. Hallmann. 2007. Pyrrolizidine Alkaloid of Chromolaena odorata act as Nematicidal Agents and Reduce
Infection of Lettuce Roots by Meloidogyne incognita. Nematology, 9(3):343-349.

Vyvyan, J. R. 2002. Allelochemicals as Leads for New Herbicides and Agrochemicals. Tetrahedro, 58 (9): 1631-1646.

Wardhiany C.K, M. Sritamin dan K. A. Yuliadhi. 2014. Studi Uji Ekstrak Beberapa Jenis Gulma dalam Menekan Nematoda Puru Akar Meloidogyne spp. pada Tanaman Tomat (Licopersicum esculentum Mill). EJurnal Agroekoteknologi Trop, 3 (1): 32-40.

Wattimena, G. A. 1987. Zat Pengatur Tumbuh. PAU Bioteknologi IPB. Bogor. 